\title{
PENGARUH HARGA DAN GAYA HIDUP (LIFE STYLE) TERHADAP KEPUTUSAN PEMBELIAN MOTOR KAWASAKI NINJA 250 CC DI CIREBON
}

\author{
The Effect of Prices and LiLife Style On the Purchase Decision of The \\ Kawasaki Ninja $250 \mathrm{CC}$ at Cirebon
}

\author{
Noerdjanah Rahayuningsih, Toandi \\ Manajemen FE Unversitas Wiralodra \\ noerjanah.unwir@unwir.ac.id
}

\begin{abstract}
ABSTRAK
Penelitian ini bertujuan untuk mengetahui seberapa besar pengaruh Harga dan Gaya Hidup Terhadap Keputusan Pembelian pada PT. Putra Mulya Citra Mobil Dealer Kawasaki Cirebon. Data pada penelitian ini diperoleh dengan observasi, wawancara, dan menggunakan koesioner yang dibagikan kepada 65 responden yang semuanya merupakan konsumen PT. Putra Mulya Citra Mobil Dealer Kawasaki Cirebon.Variabel independen penelitian ini adalah Harga dan Gaya Hidup, Keputusan Pembelian menjadi variabel dependen. Pengujian korelasi menunjukan bahwa ketiga variabel independen yang diteliti yaitu variabel Harga dan Gaya Hidup, terbukti berepengaruh positif dan signifikan terhadap variabel dependenya keputusan pembelian yaitu X1.Y diperoleh nilai 0,569 artinya harga terhadap keputusan pembelian termasuk dalam kategori sedang. X2.Y diperoleh nilai 0,513 artinya gaya hidup terhadap keputusan pembelian termasuk kategori sedang, X1.X2 diperoleh nilai 0,763 artinya harga terhadap gaya hidup termasuk dalam kategori kuat. X1 dan X2 terhadap Y diperoleh nilai 0,581 artinya harga dan gaya hidup terhadap keputusan pembelian termasuk dalam kategori sedang. Hasil koefisien determinasi kd X1.Y = 32,3\% yang berarti besarnya hubungan harga terhadap keputusan pembelian adalah $32,3 \%$ sedangkan sisanya $67,7 \%$ dipengaruhi oleh faktor lain yang tidak diteliti. Kd X2.Y = 63\% yang berarti besarnya pengaruh gaya hidup terhadap keputusan pembelian adalah $63 \%$ sedangkan sisanya $37 \%$ dipengaruhi oleh faktor lain yang tidak diteliti. Kemudian kd $X 1 . X 2$ terhadap $Y=33,7 \%$ yang berarti besarnya harga dan gaya hidup terhadap keputusan pembelian adalah 33,7 \% sedangkan sisanya $66,3 \%$ dipengaruhi oleh
\end{abstract}

faktor lain yang tidak diteliti.

Kata Kunci: Harga, Gaya Hidup, Keputusan Pembelian

\section{ABSTRACT}

This study aims to determine how much influence the Price and Lifestyle on Purchasing Decisions at PT. Putra Mulya Citra Cirebon Cirebon Car Dealer. The data in this study were obtained by observation, interviews, and using questionnaires distributed to 65 respondents who were all consumers of PT. Putra Mulya Image of Cirebon Kawasaki Car Dealer. Independent variables of this study are Price and Lifestyle, Purchasing Decisions become the dependent variable. Correlation testing shows that the three independent variables studied, namely the Price and Lifestyle variables, proved to have a positive and significant effect on the dependent variable purchasing decision, namely X1.Y obtained a value of 0.569 , meaning the price of purchasing decisions included in the medium category. X2.Y obtained a value of 0.513, which means that lifestyle towards purchasing decisions is included in the medium category, $X 1 . X 2$ obtained a value of $\mathbf{0 . 7 6 3}$, which means that prices for lifestyle are included in the strong category. $\mathrm{X} 1$ and X2 towards Y obtained a value of 0.581 which means that prices and lifestyles for purchasing decisions are included in the medium category. The results of the coefficient of determination in X1.Y = $32.3 \%$, which means the magnitude of the relationship of prices to purchasing decisions is $32.3 \%$ while the remaining $67.7 \%$ is influenced by other factors not examined. Kd X2.Y $=63 \%$, which means the magnitude of the influence of lifestyle on purchasing decisions is $63 \%$ while the remaining $37 \%$ is influenced by other 
factors not examined. Then kd X1.X2 to $Y=$ $33.7 \%$ which means the price and lifestyle of purchasing decisions are $33.7 \%$ while the remaining $66.3 \%$ is influenced by other factors not examined.

Keywords: Price, Lifestyle, Purchasing Decision

\section{PENDAHULUAN}

Menurut Kanuk (2008:8). Dipengaruhi faktor eksternal dan internal. Faktor eksternal merupakan masukan informasi bagi konsumen yang berasal dari usaha-usaha pemasaran yang dilakukan perusahaan seperti produk, harga, pelayanan, lokasi, promosi, kemudian masukan informasi yang berasal dari lingkungan sosial budaya yang meliputi keluarga, sumber informasi informal, sumber informasi non komersial lain, kelas sosial, gaya hidup dan budaya. Faktor internal adalah faktor yang timbul dari dalam diri konsumen meliputi motivasi, persepsi, pembelajaran, kepribadian, sikap dan kepercayaan Menurut Ujang Sumarwan (2011:186), menyatakan bahwa : "Keputusan Pembelian adalah konsumen membentuk preferensi atas merekmerek dalam kumpulan pilihan dan konsumen membuat niat untuk membeli produk yang di sukai. Saat melakukan pembelian, konsumen di pengaruhi faktor sikap orang lain dan faktor situasi yang tidak terantisipasi serta dapat mengubah niat pembelian." Menurut Schiffman dan Kanuk di kutip oleh Ujang Sumarwan (2014:357), menyatakan bahwa: "Keputusan Pembelian adalah suatu keputusan sebagai pemilihan suatu tindakan dari dua atau lebih memilih pilihan alternatif." Berdasarkan beberapa definisi pendapat para ahli diatas, peneliti merangkum bahwa keputusan pembelian adalah konsumen membentuk preferensi atas merekmerek dalam kumpulan pilihan dan konsumen membuat niat untuk membeli produk yang di sukai. Konsumen di pengaruhi faktor sikap orang lain dan faktor situasi yang serta dapat mengubah niat pembelian dan membeli produk untuk digunakan secara pribadi, bukan untuk tujuan bisnis atau dijual kembali kepada pihak lain dalam membuat pilihan alternative.Indikator Keputusan Pembelian, Dikutip dari rangkuman definisi diatas, ada beberapa indikator keputusan pembelian adalah sebagai berikut :Konsumen membentuk preferensi atas merek merek, Membuat niat untuk membeli produk, Faktor 
sikap orang lain, Faktor situasi, Pilihan alternatif Penjelasan PerIndikator.Faktor-faktor yang Mempengharuhi Keputusan Pembelian Menurut Kanuk (2008:509), menyatakan bahwa faktor-faktor yang mempengaruhi keputusan pembelian sebagai berikut : Faktor internal meliputi Motivasi

Motivasi Persepsi, Gaya hidup. Faktor Eksternal meliputi produk, harga, pelayanan, lokasi, promosi.

Proses Keputusan Pembelian, Menurut Ujang Sumarwan (2015:15), menyatakan bahwa ada beberapa proses pengambil keputusanan pembelian sebagai berikut: Pengenalan kebutuhan, Pencarian informasi, Evaluasi alternative, Pembelian, Konsumsi, Kepuasan. Motif-motif pembelian Menurut Buchori Alma (2016: 97), menyatakan bahwa ada beberapa motifmotif pembelian sebagai berikut: Primary buying motive, yaitu motif untuk membeli yang sebenarnya, misalnya, kalau orang mau makan ia akan mencari nasi.Selective buying motive, yaitu pemilihan tehadap barang, ini berdasakan rasio seperti membeli sesuatu karena meniru orang lain, jadi selective dapat berbentuk rationial buying motive, emotional buying motive atau impluse (dorongan seketika).Patronage buying motive, ini adalah selective buying motive yang ditunjukan kepada tempat atau toko tertentu. Pemilihan ini bisa timbul karena layanan memuaskan, tempatnya dekat, cukup persediaan barang, ada halaman parkir, orang-orang suka berbelanja disitu dsb. Menurut Sudaryono (2016: 216), menyatakan bahwa: "Harga adalah suatu nilai tukar yang bisa disamakan dengan uang atau barang lain untuk manfaat yang diperoleh dari suatu barang atau jasa bagi seseorang atau kelompok pada waktu tertentu dan tempat tertentu." Menurut Kotler dan Armstrong (2010:26), menyatakan bahwa: "Harga merupakan sejumlah uang yang harus dibayarkan oleh konsumen untuk mendapatkan sebuah produk atau jasa yang dibutuhkan atau diinginkan konsumen." Berdasarkan beberapa definisi pendapat para ahli diatas, peneliti merangkum bahwa harga adalah suatu nilai tukar yang disamakan dengan uang atau barang jasa dari sejumlah uang yang harus dibayarkan oleh konsumen untuk mendapatkan 
sebuah produk atau jasa yang dibutuhkan atau diinginkan. Indikator Harga dikutip dari rangkuman definisi diatas, ada beberapa indikator harga adalah sebagai berikut: Nilai tukar, Manfaat yang diperoleh, Sejumlah uang, Mendapatkan sebuah produk, Jasa yang dibutuhkan atau diinginkan konsumen Penjelasan Per-Indikator. Faktor-faktor yang Mempengharuhi Harga Menurut Fandy Tjipto (2015: 294) menyatakan bahwa faktor-faktor yang mempengaruhi harga dibagi menjadi dua yaitu faktor internal dan faktor eksternal.

1.Faktor Internal perusahaan meliputi :

a. Tujuan Pemasaran Perusahaan

Tujuan perusahaan bisa berupa mempertahankan kelangsungan hidup (survival) perusahaan, maksimalisasi laba, aliran kas, atau Return On Investment (ROI) saat ini, meraih pangsa pasar yang besar, dan membantu penjualan produk lainnya.

\section{b.Strategi Bauran Pemasaran}

Harga merupakan salah satu alat bauran pemasaran yang digunakan perusahaan dalam mencapai tujuan pemasarannya. Perusahaan juga sering laki menempatkan produk mereka melalui harga, dimana harga dalam hal ini menjadi faktor yang menentukan pasar produk, persaingan dan rancangan produk.

c.Biaya

Biaya menjadi dasar harga yang dapat ditetapkan perusahaan terhadap produknya agar tidak mengalami kerugian.

\section{d.Pertimbangan Organisasi}

Bukan oleh departemen pemasaran atau penjualan. Dalam perusahaan besar Peusahaanperusahaan menetapkan harga dengan berbagai cara. Dalam perusahaan kecil, harga seringkali ditetapkan oleh manajemen puncak dan, penetapan harga biasanya ditangani oleh manajermanajer divisi ataupun lini produk.

2.Faktor Eksternal penetapan harga meliputi :

a. Karakteristik Pasar dan Permintaan Sebelum menetapkan harga, seorang pemasar harus memahami hubungan antara harga dengan pasar dan permintaan atas produknya, apakah pasar tersebut pasar persaingan sempurna, persaingan monopolistik. Oligopolistik, maupun monopoli murni. 
b.Persaingan

Kebebasan perusaan dalam menetukan harga itu tergantung pada jenis pasar yang berbeda-beda.

c.Unsur-unsur lingkungan eksternal lainnya

Dalam menentukan harga perusahaan harus mempertimbangkan faktor kondisi ekonomi, kebijakan dan peraturaan pemerintah, dukungan dan reaksi distributor terhadap harga, serta aspek sosial. Peranan Harga Menurut Fandy Tjiptono (2015: 219) peranan harga penting bagi perekonomian secara makro, konsumen, dan perusahaan, yaitu:

a. Bagi perekonomian

Harga produk mempengaruhi tingkat upah, sewa, bunga dan laba. Harga melrupakan regulator dasar dalam sistem perekonomian, karena harga berpengaruh terhadap alokasi faktor-faktor produksi seperti tenaga kerja, tanah, modal, dan kewirausahaan.

b. Bagi konsumen

Mayoritas konsumen terlalu sensitif terhadap harga, namun juga mempertimbangkan faktor lain (seperti citra, merek, lokasi toko, layanan, nilai (value) dan kulitas). Selain itu, persepsi konsumen terhadap kualitas produk seringkali dipengaruhi oleh harga.

c. Bagi perusahaan

Harga produk adalah determinan utama bagi permintaan pasar atas produk bersangkutan. Harga mempengaruhi posisi bersaing dan pangsa pasar perusahaan dampaknya harga berpengaruh pada pendapatan dan laba bersih perusahaan.

Tujuan Penetapan Harga Menurut Harry Achmad Buchory dan Djaslim Saladin (2010: 160) ada 6 tujuan yang dapat diraih perusahaan melalui penetapan harga, yaitu: Bertahan hidup (survival), Maksimalisasi laba jangka pendek, Maksimalisasi hasil penjualan, Menguasai pasar secara maksimum, Kepemimpinan mutu produk, Tujuan lain.

Gaya Hidup (Life Style) Menurut Kotler (2002) dikutip Oleh Ujang Sumarwan (2014:45), menyatakan bahwa: "Gaya hidup adalah pola hidup seseorang didunia yang diekspresikan dalam aktivitas, minat, dan opininya." Menurut Minor dan Mowen (2002) dikutip Oleh 
Wahyu Nugroho (2011:173), menyatakan bahwa: "Gaya hidup Adalah pola hidup seseorang didunia dalam kehidupan sehari-hari yang dinyatakan dalam kegiatan, minat, dan pendapat." Berdasarkan beberapa definisi pendapat para ahli diatas, peneliti merangkum bahwa gaya hidup adalah pola hidup seseorang didunia yang dapat diekpresikan dalam aktivitas, minat, dan opininya. Indikator Gaya Hidup Dikutip dari rangkuman definisi diatas, ada beberapa indikator gaya hidup adalah sebagai berikut: Pola hidup seseorang, Aktivitas, Minat, Opini. Faktor-faktor yang Mempengharuhi Gaya Hidup Menurut Armstrong (2010) dikutip Oleh Susanto (2013:2), menyatakan bahwa ada beberapa Faktor-faktor yang mempengharuhi gaya hidup sebagai berikut:

1.Faktor yang bearada didalam diri (Internal)

a.Sikap

Adalah Sikap berarti suatu keadaan jiwa dan keadaan pikir yang dipersiapkan untuk memberikan tanggapan terhadap suatu objek yang diorganisasi melalui pengalaman dan mempengaruhi secara langsung pada perilaku. Keadaan jiwa tersebut sangat dipengaruhi oleh tradisi, kebiasaan, kebudayaan dan lingkungan sosialnya.

b.Pengalaman dan pengamatan

Pengalaman dapat mempengaruhi pengamatan sosial dalam tingkah laku, pengalaman dapat diperoleh dari semua tindakannya dimasa lalu dan dapat dipelajari, melalui belajar orang akan dapat memperoleh pengalaman. Hasil dari pengalaman sosial akan dapat membentuk pandangan terhadap suatu objek.

\section{c.Kepribadian}

Kepribadian adalah konfigurasi karakteristik individu dan cara berperilaku yang menentukan perbedaan perilaku dari setiap individu. d.Konsep diri

Konsep diri sudah menjadi pendekatan yang dikenal amat luas untuk menggambarkan hubungan antara konsep diri konsumen dengan image merek. Bagaimana individu memandang dirinya akan mempengaruhi minat terhadap suatu objek. Konsep diri sebagai inti dari pola kepribadian akan menentukan perilaku individu dalam menghadapi 
permasalahan hidupnya, karena konsep diri merupakan frame of reference yang menjadi awal perilaku.

e.Motif

Motif kebutuhan untuk merasa aman dan kebutuhan terhadap prestise merupakan beberapa contoh tentang motif. Jika motif seseorang terhadap kebutuhan akan prestise itu besar maka akan membentuk gaya hidup yang cenderung mengarah kepada gaya hidup hedonis.

f.Persepsi

$\underline{\text { Adalah proses dimana seseorang }}$ memilih, mengatur, dan menginterpretasikan informasi untuk membentuk suatu gambar yang berarti mengenai dunia.

2.Faktor yang berasal dari luar (Eksternal)

a.Kelompok acuan

adalah kelompok yang memberikan pengaruh langsung atau tidak langsung terhadap sikap dan perilaku seseorang. Kelompok yang memberikan pengaruh langsung adalah kelompok dimana individu tersebut menjadi anggotanya dan saling berinteraksi, sedangkan kelompok yang memberi pengaruh tidak langsung adalah kelompok dimana individu tidak menjadi anggota didalam kelompok tersebut. Pengaruh-pengaruh tersebut akan menghadapkan individu pada perilaku dan gaya hidup tertentu.

b.Keluarga

Keluarga memegang peranan terbesar dan terlama dalam pembentukan sikap dan perilaku individu. Hal ini karena pola asuh orang tua akan membentuk kebiasaan anak yang secara tidak langsung mempengaruhi pola hidupnya.

c.Kelas social

Adalah sebuah kelompok yang relatif homogen dan bertahan lama dalam sebuah masyarakat, yang tersusun dalam sebuah urutan jenjang, dan para anggota dalam setiap jenjang itu memiliki nilai, minat, dan tingkah laku yang sama. Ada dua unsur pokok dalamsistem sosial pembagian kelas dalam masyarakat, yaitu kedudukan(status) dan peranan. Kedudukan sosial artinya tempat seseorang dalam lingkungan pergaulan, prestise hak-haknya serta kewajibannya. Kedudukan sosial ini dapat dicapai oleh seseorang dengan usaha yang sengaja maupun diperoleh 
Noerdjanah Rahayuningsih, Toandi

karena kelahiran. Peranan merupakan aspek yang dinamis dari kedudukan. Apabila individu melaksanakan hak dan kewajibannya sesuai dengan kedudukannya maka ia menjalankan suatu peranan.

d.Kebudayaan

Kebudayaan yang meliputi pengetahuan, kepercayaan, kesenian, moral, hukum, adat istiadat, dan kebiasaan-kebiasaan yang diperoleh individu sebagai anggota masyarakat.

Kebudayaan terdiri dari segala sesuatu yang dipelajari dari pola-pola perilaku yang normatif, meliputi ciri-ciri pola pikir, merasakan dan bertindak.

Dimensi Gaya Hidup Gaya hidup akan berkembang pada masingmasing dimensi AIO (Activity, Interest, Opinion) seperti telah diindetifikasi oleh Solomon (1999:79) dikutip Oleh Ujang Sumarwan (2014:47).
Tabel 1 Dimensi Gaya Hidup

\begin{tabular}{|c|c|c|c|}
\hline AKTIVITAS & MINAT & OFINI & DEMOGRAFIK \\
\hline Bekerja & Kduarga & Diri sendiri & Usia \\
\hline Hobi & Rumah & Isu sosial & Pendiditann \\
\hline Kegiatan sosial & Pelkajajan & Politik & Pendapatan \\
\hline Liburan & Masyaratat & Bisnis & Pekerja3n \\
\hline Hibursn & Rekresai & Elronomi & Keluarga beent \\
\hline 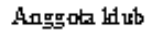 & Fashion & Pendicitan & Jenis rumah \\
\hline Masyaratat & Materanan & Produk & Geografi \\
\hline Belanja & Media & Masa depan & Kota bear \\
\hline Olah fag & Kebarhasilan & Budays & Siklus hičup \\
\hline
\end{tabular}

Hipotesis Penelitian

Hipotesis merupakan dugaan sementara terhadap permasalah yang diteliti dan akan diuji kebenarannya. Karena itu hipotesis sering pula dikatakan dugaan yang mungkin benar dan mungkin salah.

\section{Gambar1}

Diagram Hipotesis Penelitian

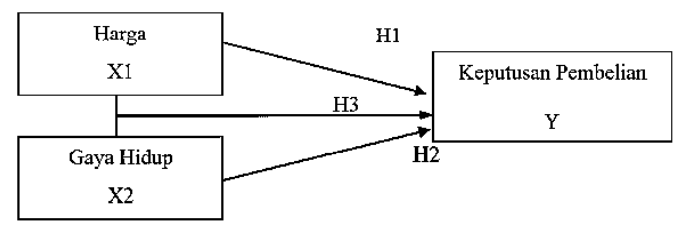

Berdasarkan latar belakang dan kerangka pemikiran yang telah diuraikan diatas, dapat dkatakan bahwa diduga harga dan gaya hidup terhadap keputusan pembelian, maka peneliti mengajukan hipotesis penelitian sebagai berikut:

1.H1 = Diduga terdapat pengaruh harga terhadap keputusan pembelian. 
2.H2 = Diduga terdapat pengaruh gaya hidup terhadap keputusan pembelian.

3.H3 = Diduga terdapat pengaruh harga dan gaya hidup terhadap keputusan pembelian.

\section{METODE PENELITIAN}

Menurut Sugiyono

menyatakan bahwa secara umum metode penelitian diartikan sebagai "cara ilmiah untuk mendapatkan data dengan tujuan dan kegunaan tertentu". Menurut Sugiyono (2017:29) menyatakan bahwa: "Statistik deskriptif adalah statistik yang berfungsi untuk mendiskripsikan atau memberi gambaran terhadap obyek yang diteliti melalui data sampel atau populasi sebagaimana adanya, tanpa melakukan analisis dan membuat kesimpulan yang berlaku untuk umum.” Menurut Sugiyono (2017:61), menyatakan bahwa: "populasi adalah wilayah generalisasi yang terdiri atas objek/subjek yang mempunyai kualitas dan karakteristik tertentu yang di tetapkan oleh peneliti untuk dipelajari dan kemudian ditarik kesimpulannya." Dalam penelitian ini populasinya adalah Konsumen Dealer Kawasaki
diPT. Mulya Putra Citra Mobil, yang ditarik dalam 3 bulan yaitu pada bulan Mei-juli 2017. Sebanyak 188 konsumen pembelian motor kawasaki ninja 250cc. Menurut Sugiyono (2017:61), menyatakan bahwa: "Sampel adalah bagian dari jumlah dan karakteristik yang dimiliki oleh populasi.” Besarnya populasi yang ada hanya akan menyulitkan peneliti dalam melakukan penelitian dan tidak akan mungkin dipelajari oleh peneliti secara keseluruhan karena terbatasnya dana, waktu dan tenaga, maka untuk mempermudahnya peneliti akan menggunakan sampel yang diambil dari populasi itu. Teknik pengambilan sampel yang digunakan peneliti yaitu Simple Random Sampling yang artinya adalah pengambilan anggota sampel dari populasi dilakukan secara acak tanpa memperhatikan strata yang ada dalam populasi itu. Sugiyono (2017: 63). Sedangkan untuk mengetahui berapa sampel yang akan diambil penulis menggunakan rumus slovin, sampel yang digunakan dalam penelitian ini sebanyak 65 responden dari jumlah populasi sebanyak 188. 
A. Teknik Pengumpulan Data kuesioner juga cocok digunakan bila Penelitian jumlah responden cukup besar dan a.Study Lapangan (Field Research) Penulis melakukan penelitian langsung di lapangan untuk memperoleh data yang diperlukan, dalam penelitian ini penulis menggunakan:

b.Interview (Wawancara)

Merupakan teknik penelitian dimana peneliti mengadakan komunikasi langsung dengan pegawai pada perusahaan tempat penelitian, berhubungan dengan masalah yang sedang diteliti.

\section{c.Observasi (Pengamatan)}

Merupakan teknik penelitian dimana peneliti melakukan pengamatan secara langsung terhadap kegiatan perusahaan sehari-hari.

d.Kuesioner (Angket)

Kuesioner merupakan teknik pengumpulan data yang dilakukan dengan cara memberi seperangkat pertanyaan atau pernyataan tertulis kepada responden untuk dijawabnya. Kuesioner merupakan teknik pengumpulan data yang efisien bila peneliti tahu dengan pasti variabel yang akan diukur dan tahu apa yang bisa diharapkan dari responden. Selain itu, tersebar diwilayah yang luas. Kuesioner dalam penelitian ini menggunakan statement atau pernyataan yang akan diajukan kepada responden.

B. Jenis Instrumen Keputusan Pembelian

Instrumen yang digunakan dalam penelitian ini berupa angket atau koesioner yang dibuat sendiri oleh peneliti. Menurut Sugiyono (2014:34), menyatakan bahwa:

"Instrumen Penelitian adalah suatu pengumpulan alat data yang digunakan untuk mengukur fenomena alam atau social yang diamati, dengan dengan demikian penggunaan instrument penelitian yaitu untuk mencari informasi yang lengkap mengenai suatu masalah, fenomena alam maupun sosial. Instrumen yang digunakan dalam penelitian ini dimaksudkan untuk menghasilkan data yang akurat yaitu dengan menggunakan skala likert." Menurut Sugiyono (2017:134), menyatakan bahwa: 
Skala likert adalah digunakan untuk mengukur suatu sikap, pendapat dan persepsi seseorang atau kelompok tentang suatu fenomena sosial. Dalampenelitian ini peneliti menggunakan jenis instrumen angket atau kuesioner dengan pemberian skor sebagai berikut.
a. Sangat Baik
Diberi Skor 5
b. Baik
Diberi Skor 4
c. Cukup
Diberi Skor 3
d. Tidak Baik
Diberi Skor 2
e. Sangat Tidak Baik Diberi Skor 1

C. Pengujian Validitas Keputusan Pembelian

Menurut Sugiyono (2017: 1), menyatakan bahwa:

"Validitas dalam penelitian ini adalah drajat ketepatan antara data yang sesungguhnya terjadi pada obyek dengan data yang dapat dilaporkan oleh peneliti”. Instrumen yang valid berarti alat ukur yang digunakan untuk mendapatkan data (mengukur) itu valid. Valid berarti instrumen tersebut dapat digunakan untuk mengukur apa yang hendak diukur. Sugiyono (2017: 348) "Dengan demikian, data yang valid adalah data yang berbeda atau terdapat kesamaan antara data yang terkumpul dengan data yang sesungguhnya terjadi pada objek yang diteliti."

Tabel 2

\begin{tabular}{|c|c|c|c|}
\hline \multirow[b]{2}{*}{$\begin{array}{l}\text { Nombor } \\
\text { Pertanyazan }\end{array}$} & \multicolumn{2}{|c|}{$\underset{\substack{\text { Keputusan Pembelian } \\
\text { Yaliditas }}}{ }$} & \multirow[b]{2}{*}{ Kesimpulan } \\
\hline & $\begin{array}{c}\text { Kotisien Korelazi } \\
\text { (f hitung) }\end{array}$ & $\begin{array}{c}\text { Nilai Kritis } \\
\text { (f thal dengan } \\
\text { taraf aignifilan 5\%) }\end{array}$ & \\
\hline 1 & 0,688 & 0,632 & Yalid \\
\hline 2 & 0,203 & 0,632 & Yalid \\
\hline 3 & 0,818 & 0,632 & Valid \\
\hline 4 & 0,696 & 0,632 & Valid \\
\hline 5 & 0,614 & 0,632 & Yalid \\
\hline 6 & 0,817 & 0,632 & Yalid \\
\hline 7 & 0,834 & 0,632 & Yalid \\
\hline 8 & 0,664 & 0,632 & Valid \\
\hline 9 & 0,796 & 0,632 & Yalid \\
\hline 10 & 0,655 & 0,632 & Yalid \\
\hline
\end{tabular}

Pengujian Reliabilitas

Menurut Sugiyono (2017: 354) menyatakan bahwa:

"Pengujian

Reliabilitas instrumen dapat dilakukan secara eksternal maupun internal. Secara eksternal pengujian dapat dilakukan dengan test-retest (stability), equivalent, dan gabungan keduanya. Secara internal reliabilitas instrumen dapat diuji dengan menganalisis konsistensi butir-butir yang ada pada instrumen dengan teknik tertentu (internal consistency).”

D. Perhitungan Reabilitas Keputusan Pembelian

Dari penghasilan penghitungan reliabilitas angket keputusan 
pembelian diperoleh $r=0,750$ dengan $\mathrm{N}=10$ dan taraf signifikan 5\% di dapat $r$ tabel $=0,576$ sehingga $r$ hitung $>r$ tabel $(0,750>0,576)$ maka dapat disimpulkan bahwa angket keputusan pembelian reliabel.

E. Pengujian Validitas

Harga Menurut Sugiyono (2017: 1), menyatakan bahwa : "Validitas dalam penelitian ini adalah drajat ketepatan antara data yang sesungguhnya terjadi pada obyek dengan data yang dapat dilaporkan oleh peneliti."Adapun menurut Sugiyono (2017: 348), menyatakan bahwa: “Instrumen yang valid berarti alat ukur yang digunakan untuk mendapatkan data (mengukur) itu valid. Valid berarti instrumen tersebut dapat digunakan untuk mengukur apa yang hendak diukur." Dengan demikian, data yang valid adalah data yang berbeda atau terdapat kesamaan antara data yang terkumpul dengan data yang sesungguhnya terjadi pada objek yang diteliti.

Tabel 3.

Rekapitulasi Validitas Instrumen Harga

\begin{tabular}{|c|c|c|c|}
\hline \multirow[b]{2}{*}{$\begin{array}{c}\text { Nomor } \\
\text { Perbaryasan }\end{array}$} & \multicolumn{2}{|r|}{ Validitas } & \multirow[b]{2}{*}{ Kesimpulan } \\
\hline & $\begin{array}{c}\text { Kosfisien Kor }{ }_{\text {(I hai }} \text { itung) }\end{array}$ & $\begin{array}{c}\text { Nilai Kritis (f tabsel } \\
\text { dengan taraf } \\
\text { aignifilan 5\%) }\end{array}$ & \\
\hline 1 & 0,769 & 0,632 & Valid \\
\hline 2 & 0,725 & 0,632 & Valid \\
\hline 3 & 0,767 & 0,632 & Valid \\
\hline 4 & 0,732 & 0,632 & Valid \\
\hline 5 & 0,644 & 0,632 & Yalid \\
\hline 6 & 0,701 & 0,632 & Valid \\
\hline 7 & 0,812 & 0,632 & Valid \\
\hline 8 & 0,663 & 0,632 & Valid \\
\hline 9 & 0,835 & 0,632 & Valid \\
\hline 30 & 0,677 & 0,632 & Valid \\
\hline
\end{tabular}

F. Pengujian Reliabilitas Harga

Menurut Sugiyono (2017: 354), menyatakan bahwa:

"Pengujian reliabilitas instrumen dapat dilakukan secara eksternal maupun internal. Secara eksternal pengujian dapat dilakukan dengan testretest (stability), equivalent, dan gabungan keduanya. Secara internal reliabilitas instrumen dapat diuji dengan menganalisis konsistensi butirbutir yang ada pada instrumen dengan teknik tertentu (internal consistency)."

G. Perhitungan Reabilitas Harga

Dari penghasilan penghitungan reliabilitas angket harga diperoleh $\mathrm{r}=$ 0,996 dengan $\mathrm{N}=10$ dan taraf signifikan $5 \%$ di dapat $r$ tabel $=0,576$ sehingga $r$ hitung > r tabel $(0,996>0,576)$ maka dapat disimpulkan bahwa angket harga reliabel. 


\section{H. Pengujian Validitas Gaya Hidup}

Menurut Sugiyono (2017: 1), menyatakan bahwa: "Validitas dalam penelitian ini adalah drajat ketepatan antara data yang sesungguhnya terjadi pada obyek dengan data yang dapat dilaporkan oleh peneliti." Menurut Sugiyono (2017: 348), menyatakan bahwa: "Instrumen yang valid berarti alat ukur yang digunakan untuk mendapatkan data (mengukur) itu valid. Valid berarti instrumen tersebut dapat digunakan untuk mengukur apa yang hendak diukur" Dengan demikian, data yang valid adalah data yang berbeda atau terdapat kesamaan antara data yang terkumpul dengan data yang sesungguhnya terjadi pada objek yang diteliti.

Tabel 4

Rekapitulasi Validitas Instrumen Gaya

\begin{tabular}{|c|c|c|c|}
\hline \multicolumn{4}{|c|}{ Hidup } \\
\hline \multirow[b]{2}{*}{$\begin{array}{l}\text { Nomar } \\
\text { Pertangazan }\end{array}$} & \multicolumn{2}{|c|}{ Validitas } & \multirow[b]{2}{*}{ Kesimpulan } \\
\hline & $\begin{array}{c}\text { Koefisien Karelasi } \\
\text { (r hithng) }\end{array}$ & $\begin{array}{c}\text { Nilai Kritis } \\
\text { (x tabel dengan } \\
\text { brafi signifilan } \\
5 \%)\end{array}$ & \\
\hline 1 & $0,8=0$ & 0,632 & Yalid \\
\hline 2 & 0,686 & 0,632 & Yalid \\
\hline 3 & 0,783 & 0,632 & Valid \\
\hline 4 & 0,787 & 0,632 & Valid \\
\hline 5 & 0,850 & 0,632 & Valid \\
\hline 6 & 0,744 & 0,632 & Yalid \\
\hline$\tau$ & 0,777 & 0,632 & Yalid \\
\hline 8 & 0,727 & 0,632 & Valid \\
\hline
\end{tabular}

Pengujian Reliabilitas

Menurut Sugiyono (2017: 354) menyatakan bahwa: "Pengujian Reliabilitas instrumen dapat dilakukan secara eksternal maupun internal. Secara eksternal pengujian dapat dilakukan dengan test- retest (stability), equivalent, dan gabungan keduanya. Secara internal reliabilitas instrumen dapat diuji dengan menganalisis konsistensi butir- butir yang ada pada instrumen dengan teknik tertentu (internal consistency)."

I. Perhitungan Reabilitas Gaya Hidup

Dari penghasilan penghitungan reliabilitas angket harga diperoleh $\mathrm{r}=$ 0,994 dengan $\mathrm{N}=10$ dan taraf signifikan $5 \%$ di dapat $r$ tabel $=0,576$ sehingga $r$ hitung > r tabel $(0,994>0,576)$ maka dapat disimpulkan bahwa angket gaya hidup reliabel.

\section{J. Analisis Deskriptif}

Menurut Sugiyono

(2013:29) menyatakan bahwa: "Statistik yang berfungsi untuk mendeskripsikan atau memberikan gambaran terhadap objek yang diteliti melalui data sampel atau populasi sebagaimana adanya, tanpa 
melakukan analisis dan membuat kesimpulan yang berlaku untuk umum." Uji Normalitas

Uji normalitas digunakan agar data-data penelitian dapat dipertanggung jawabkan. Hal ini penting untuk mengetahui apakah data yang diperoleh dalam penelitian tersebut normal atau tidak. Menurut Sugiyono (2017: 107) pengujian normalitas data dapat mengunakan rumus Chi Kuadrat Analisis Simultan

Analisis Korelasi Sederhana Menurut Sugiyono (2017:228), menyatakan bahwa: "Teknik korelasi ini digunakan untuk mencari hubungan dan membuktikan hipotesis hubungan dua variabel bila data kedua variabel berbentuk interval atau ratio, dan sumber data dari dua variabel atau lebih tersebut adalah sama."

K. Analisis Korelasi Berganda,

Menurut Sugiyono (2017: 231) menyatakan bahwa: "Teknik korelasi ini digunakan untuk dua variabel independen dan satu dependen".

Tabel 5

Pedoman Untuk Memberikan Implementasi Koefisien Korelasi

\begin{tabular}{|c|c|}
\hline $\begin{array}{c}\text { Interval } \\
\text { Koefisien }\end{array}$ & Tingkat Hubungan \\
\hline $0,80-1,000$ & Sangat Kuat \\
\hline $0,60-0,799$ & Kuat \\
\hline $0,40-0,559$ & Sedang \\
\hline $0,20-0,399$ & Rendah \\
\hline $0,00-199$ & Sangat Rendah \\
\hline
\end{tabular}

Kuat tidaknya hubungan antara $X_{1}$ terhadap $\mathrm{Y}, X_{2}$ terhadap $\mathrm{Y}$, serta $X_{1}$ dan $X_{2}$ terhadap Y dapat dinyatakan dengan fungsi linear (paling tidak mendekati), diukur dengan suatu nilai yang disebut koefisien korelasi. Nilai koefisien korelasi ini paling sedikit -1 dan paling besar 1. Jadi kalau $r=$ Koefisien korelasi, nilai $r$ dapat dinyatakan sebagai berikut:

$$
-1<\mathrm{r}<1
$$

Artinya:

$\mathrm{r}=1$, hubungan $\mathrm{X}$ dan $\mathrm{Y}$ sempurna dan positif (mendekati 1, hubungan sangat kuat dan positif)

$\mathrm{r}=-1$, hubungan $\mathrm{X}$ dan $\mathrm{Y}$ sempurna dan negatif (mendekati 1, hubungan sangat kuat dan negatif)

$\mathrm{r}=0$, hubungan $\mathrm{X}$ dan $\mathrm{Y}$ lemah sekali atau tidak ada hubungan

L. Hipotesis Statistika

Adapun hipotesis statistik yang peneliti ajukan sebagai berikut:

1. $\mathrm{Ho}_{1}: r_{1}=0$ Diduga tidak 
terdapat pengaruh harga terhadap Keputusan pembelian

Ha $1: r_{1} \neq 0$ Diduga terdapat pengaruh harga terhadap keputusan pembelian.

2. $\mathrm{Ho}_{2}: r_{2}=0$ Diduga tidak terdapat pengaruh gaya hidup terhadap keputusan pembelian

Ha2: $r_{2} \neq 0$ Diduga terdapat pengaruh gaya hidup terhadap keputusan pembelian

1. Ho3: $r_{1.2}=0$ Diduga tidak terdapat pengaruh harga dan gaya hidup terhadap keputusan pembelian

$\mathrm{Ha}_{3}: r_{1.2} \neq 0$ Diduga terdapat pengaruh harga dan gaya hidup terhadap keputusan pembelian

Analisis Koefisien Determinasi

Koefisien determinasi digunakan untuk melihat seberapa besar konstribusi variabel $X_{1}$ (Harga) dan $X_{2}$ (Gaya Hidup) terhadap $Y$ (Keputusan pembelian), biasanya dinyatakan dengan persen (\%). Koefisien determinasi dapat dihitung dengan rumus sebagai berikut:

$\mathrm{Kd}=r^{2} \mathrm{x} 100 \%$

\section{HASIL DAN PEMBAHASAN}

Tabel 6

Rekapitulasi Jawaban Respoden Terhadap Harga

\begin{tabular}{|c|c|c|c|}
\hline NoItem & hodifator Harga & Shar & Total Skot \\
\hline $1-2$ & Nilai tularer & $\begin{array}{l}286 \\
280\end{array}$ & 546 \\
\hline \multirow[t]{2}{*}{$3-4$} & Mantat yang dipsoleh & 279 & 567 \\
\hline & & 288 & \\
\hline \multirow[t]{2}{*}{$5-6$} & Sejumiah uang & 285 & 569 \\
\hline & & 284 & \\
\hline \multirow[t]{2}{*}{$7-8$} & Mendapatten sebuah prociuk & 285 & 574 \\
\hline & & 289 & \\
\hline \multirow{2}{*}{ 9-10 } & Jasa yang dibu tuhtan atau & 284 & \multirow{2}{*}{368} \\
\hline & dingintan knomsung & 284 & \\
\hline \multicolumn{3}{|c|}{ Jurrlah } & 2824 \\
\hline
\end{tabular}

Berdasarkan jumlah skor keseluruhan indikator adalah 2824 atau $2824 / 3250 \times 100 \%=86,89 \%$ artinya saluran distribusi termasuk dalam klasifikasi "Sangat Baik"

Tabel 7

Rekapitulasi Jawaban Respoden Terhadap Gaya Hidup

\begin{tabular}{|c|c|c|c|}
\hline $\begin{array}{c}\text { No Item } \\
1-2\end{array}$ & $\begin{array}{l}\text { Indikator Gaya Hidup } \\
\text { Fola hiòup saseorang }\end{array}$ & $\begin{array}{l}\text { Skar } \\
282 \\
290\end{array}$ & $\begin{array}{c}\text { Toks Skor } \\
572\end{array}$ \\
\hline 34 & Alktiviass & 296 & 396 \\
\hline $5-6$ & Minat & $\begin{array}{l}300 \\
294 \\
285\end{array}$ & 579 \\
\hline \multirow[t]{2}{*}{$7-8$} & \multirow[b]{2}{*}{ Jumlah } & 296 & 391 \\
\hline & & 295 & 2338 \\
\hline
\end{tabular}

Berdasarkan jumlah skor keseluruhan indikator saluran distribusi adalah 2338 atau 2338/2600x100\% = $89,92 \%$ artinya saluran distribusi termasuk dalam klasifikasi "Sangat Baik" 
Tabel 8

Rekapitulasi Jawaban Respoden Terhadap Keputusan Pembelian

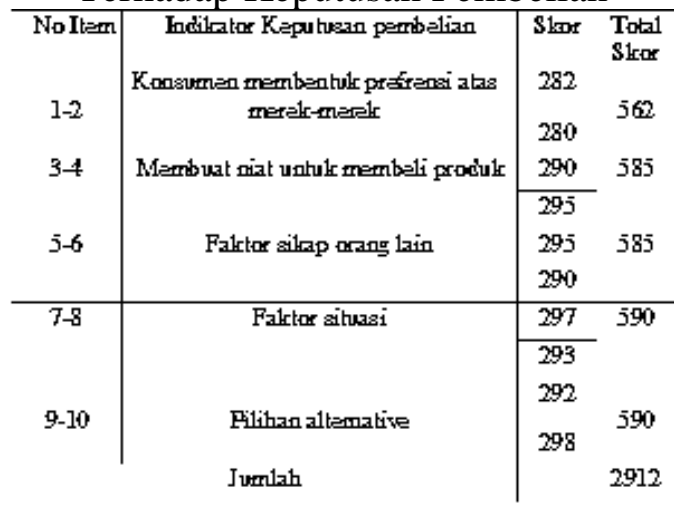

Berdasarkan jumlah skor

keseluruhan indikator adalah 2912 atau $2912 / 3250 \times 100 \%=89,6 \%$ artinya saluran distribusi termasuk dalam klasifikasi "Sangat Baik"

Tabel 9

Uji Normalitas Harga

\begin{tabular}{|c|cc|cc|c|} 
frelas & Fo & Fh & fofh & (fo-fh $^{2}$ & (fo-fh/f) $^{2}$ \\
\hline $36-38$ & 4 & 1,755 & 2,245 & 5,040025 & 0,445434 \\
$39-41$ & 9 & 8,7945 & 0,2055 & 0,04223 & 4,86618 \\
\hline $42-44$ & 23 & 22,1845 & 0,8155 & 0,66504 & 1,226242 \\
$45-47$ & 23 & 22,1845 & 0,8155 & 0,66504 & 0,009978 \\
\hline $48-50$ & 6 & 8,7945 & $-2,7945$ & 7,80923 & 0,887968 \\
$51-53$ & 0 & 1,755 & $-1,755$ & 3,080025 & 1,755 \\
\hline$?$ & 65 & & & & 9,210801 \\
\hline
\end{tabular}

Berdasarkan tabel diatas diperoleh nilai Chi Kuadrat hitung didapat sebesar 9,210 sedangkan Chi Kuadrat tabel dengan Df $=\mathrm{k}-1$ atau 6 $1=5$ dengan taraf signifikasi $5 \%$ yaitu sebesar 11,070 sehingga Chi Kuadrat hitung lebih kecil $(<)$ dari Chi Kuadrat tabel $(9,210<11,070)$ sehingga dapat disimpulkan bahwa distribusi frekuensi atau sebaran data normal.
Gambar 2

Uji Normalitas Harga

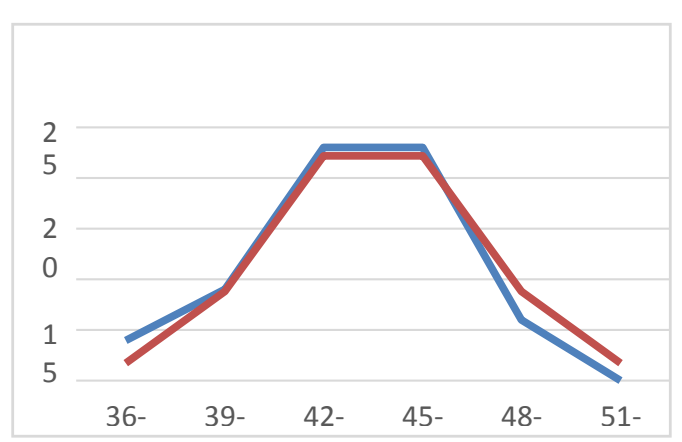

Tabel 10

Uji Normalitas Gaya Hidup

\begin{tabular}{|c|c|c|c|c|c|}
\hline felas & fo & Fh & fo-fh & $\left(\mathrm{fo}_{\mathrm{o}-\mathrm{fh})^{2}}\right.$ & (Eofflith) \\
\hline $28-30$ & 3 & $1,75=$ & 1,245 & 1,500025 & 0,883205 \\
\hline 31-33 & 9 & $8,794=$ & 02055 & 0,04223 & 0,004802 \\
\hline $34-36$ & 19 & 22,1845 & $-3,1845$ & 10,14104 & 0,457123 \\
\hline $37-39$ & 19 & $22,184=$ & $-3,1845$ & 10,14104 & 0,457123 \\
\hline $40-2$ & 15 & 8,7945 & 62055 & 38,50823 & 4,372672 \\
\hline $43-45$ & 0 & $1,75=$ & $-1,753$ & 3,080025 & 1,755 \\
\hline$?$ & 65 & & & & 7,935925 \\
\hline
\end{tabular}

Berdasarkan tabel diatas diperoleh nilai Chi Kuadrat hitung didapat sebesar 7,935 sedangkan Chi Kuadrat tabel dengan $\mathrm{Df}=\mathrm{k}-1$ atau 6 $1=5$ dengan taraf signifikasi $5 \%$ yaitu sebesar 11.070 sehingga Chi Kuadrat hitung lebih kecil $(<)$ dari Chi Kuadrat tabel $(7,935<11,070)$ sehingga dapat disimpulkan bahwa distribusi frekuensi atau sebaran data normal. 
Gambar 3

Uji Normalitas Gaya Hidup

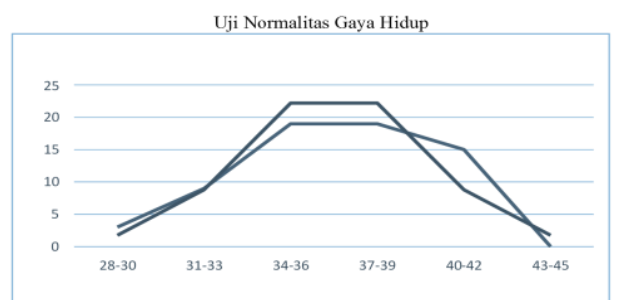

Tabel 11

Uji Normalitas Keputusan Pembelian

\begin{tabular}{c|cc|cc|c|} 
kelas & Fo & Fh & fofh & (fofh) $^{\text {(f) }}$ & (fo-fh/fh) $^{2}$ \\
\hline $37-39$ & 3 & 1,755 & 1,245 & 1,550025 & 0,833205 \\
$40-42$ & 10 & 8,7945 & 1,2055 & 1,45323 & 0,165243 \\
\hline $43-45$ & 20 & 22,1845 & $-2,1845$ & 4,77204 & 0,215107 \\
$46-48$ & 20 & 22,1845 & $-2,1845$ & 4,77204 & 0,215107 \\
\hline $49-51$ & 12 & 8,7945 & 3,2055 & 10,27523 & 1,16837 \\
$52-54$ & 0 & 1,755 & $-1,755$ & 3,080025 & 1,755 \\
$?$ & 65 & & & & 4,400032
\end{tabular}

Berdasarkan tabel diatas diperoleh nilai Chi Kuadrat hitung didapat sebesar 4,402 sedangkan Chi Kuadrat tabel dengan Df $=\mathrm{k}-1$ atau 6 $1=5$ dengan taraf signifikasi $5 \%$ yaitu sebesar 11,070 sehingga Chi Kuadrat hitung lebih kecil $(<)$ dari Chi Kuadrat tabel $(4,402<11,070)$ sehingga dapat disimpulkan bahwa distribusi frekuensi atau sebaran data tidak normal.

\section{Gambar 4}

Uji Normalitas Keputusan Pembelian

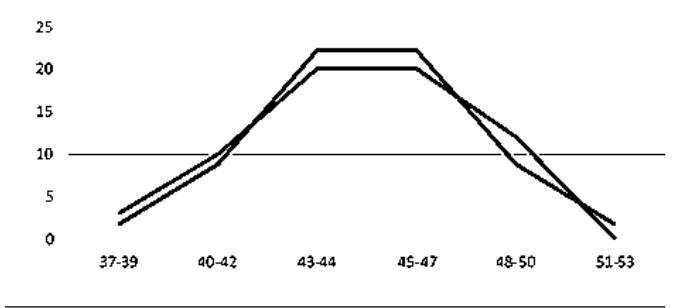

Analisis Harga Terhadap Keputusan Pembelian

Hasil uji normalitas diatas (Chi Kuadrat) dari variabel X1 dan Y, diketahui bahwa sebaran data yang diperoleh berdistribusi normal, sehingga untuk mengetahui pengaruh Harga terhadap Keputusan Pembelian mengunakan korelasi Produk Moment Pearson.

Dari perhitungan korelasi diatas dapat disimpulkan bahwa nilai $r$ hitung sebesar 0,569 termasuk kategori sedan Analisis Gaya Hidup Terhadap Keputusan Pembelian

Hasil uji normalitas diatas (Chi Kuadrat) dari variabel $\mathrm{X} 2$ dan $\mathrm{Y}$, diketahui bahwa sebaran data yang diperoleh berdistribusi normal, sehingga untuk mengetahui pengaruh Gaya Hidup terhadap Keputusan Pembelian menggunakan korelasi Produk Moment Pearson.

Dari perhitungan korelasi diatas dapat disimpulkan bahwa nilai $r$ hitung sebesar 0,513 termasuk kategori sedang. Analisis Harga Terhadap Gaya Hidup, Hasil uji normalitas diatas (Chi Kuadrat) dari variabel $\mathrm{X} 1$ dan $\mathrm{X} 2$, diketahui bahwa sebaran data yang 
diperoleh berdistribusi normal, sehingga untuk mengetahui pengaruh Harga terhadap Gaya Hidup menggunakan korelasi Produk Moment Pearson.

Dari perhitungan korelasi diatas dapat disimpulkan bahwa nilai $r$ hitung sebesar 0,763 termasuk kategori kuat. Analisis Harga dan Gaya Hidup Terhadap Keputusan Pembelian, Korelasi ganda merupakan angka yang menunjukan arah dan kuatnya hubungan antara dua variabel independen secara bersama-sama atau lebih dari satu variabel dependen. Jadi analisis korelasi ganda bertujuan untuk mengetahui koefisien korelasi antara variabel Harga (X1) dan Gaya Hidup (X2) terhadap Keputusan Pembelian (Y) secara simultan atau bersamasama. Dari hasil perhitungan diperoleh koefisien korelasi sebesar 0.581 yang termasuk kategori sedang. Dapat disimpulkan bahwa pengaruh harga dan gaya hidup terhadap keputusan pembelian adalah searah dan positif.

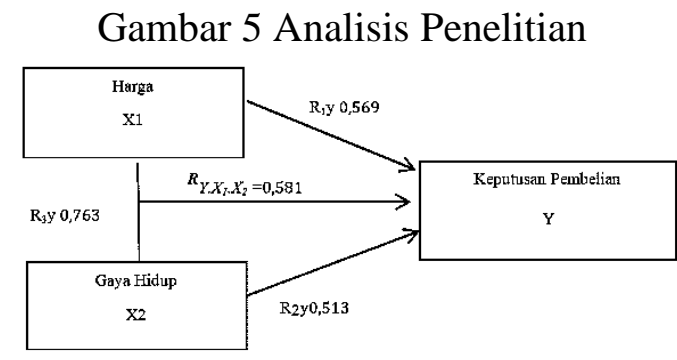

Koefisien Determinasi Harga Terhadap Keputusan Pembelian

$\mathrm{Kd}=\mathrm{r}^{2} \times 100 \%$

$\mathrm{Kd}=(0,569)^{2} \times 100 \% \mathrm{Kd}=(0,323) \mathrm{x}$ $100 \%$

$\mathrm{Kd}=32,3 \%$

Berdasarkan perhitungan diatas dapat disimpulkan bahwa, harga terhadap keputusan pembelian memiliki kontribusi sebesar 32,3\% Sedangkan sisanya 67,7 \% dipengaruhi oleh faktor-faktor lainnya yang tidak diteliti.

Koefisien Determinasi Gaya Hidup Terhadap Keputusan Pembelian

$\mathrm{Kd}=\mathrm{r}^{2} \times 100 \%$

$\mathrm{Kd}=(0,513)^{2} \times 100 \% \mathrm{Kd}=(0,63) \mathrm{x}$ $100 \%$

$\mathrm{Kd}=63 \%$

Berdasarkan perhitungan diatas dapat disimpulkan bahwa, gaya hidup terhadap keputusan pembelian memiliki kontribusi sebesar 63\%. Sedangkan sisanya $37 \%$ dipengaruhi 
oleh faktor-faktor lainnya yang tidak diteliti.

Koefisien Determinasi Harga dan Gaya Hidup Terhadap Keputusan Pembelian $\mathrm{Kd}=\mathrm{r}^{2} \times 100 \%$ $\mathrm{Kd}=(0,581)^{2} \times 100 \% \mathrm{Kd}=(0,337) \mathrm{x}$ $100 \% \mathrm{Kd}=33,7 \%$

Berdasarkan perhitungan diatas dapat disimpulkan bahwa, Harga dan Gaya Hidup terhadap Keputusan Pembelian memiliki kontribusi sebesar $33,7 \%$ Sedangkan sisanya $66,3 \%$ dipengaruhi oleh faktor-faktor lainnya yang tidak diteliti.

\section{KESIMPULAN DAN SARAN}

Kesimpulan

1. Harga berdasarkan tanggapan responden pada indikator nilai tukar, manfaat yang diperoleh, sejumlah uang, mendapatkan sebuah produk, jasa yang dibutuhkan atau diinginkan konsumen yaitu : $86,89 \% \%$ termasuk dalam kategori sangat baik.

2. Gaya hidup berdasarkan tanggaan responden pada indikator pola hidup seseorang, aktivitas, minat, opini yaitu : 89,92 termasuk dalam kategori sangat baik.
3. Keputusan pembelian berdasarkan tangggapan responden pada indikator konsumen membentuk preferensi atas merek-merek, membuat niat untuk membeli produk, faktor sikap orang lain, faktor situasi, pilihan alternatif yaitu $89,6 \%$ termasuk dalam kategori sangat baik.

4. Hubungan harga terhadap keputusan pembelian masuk dalam kategori sedang, dilihat dari hasil analisis korelasi antara harga terhadap keputusan pembelian yaitu: $r_{x 1 y}=0,569$ dan adanya pengaruh harga terhadap keputusan pembelian dari hasil koefisien determinasi $\mathrm{kd} \quad x_{1} \mathrm{y}=$ sebesar $11732,3 \%$ Sedangkan sisanya 67,7 $\%$ dipengaruhi oleh faktor-faktor lainnya yang tidak diteliti.

5. Hubungan gaya hidup terhadap keputusan pembelian masuk dalam kategori sedang dilihat dari hasil analisis korelasi antara gaya hidup terhadap keputusan pembelian yaitu: $r_{x 2 y}=0,513$ dan adanya pengaruh gaya hidup terhadap keputusan pembelian dari hasil koefisien determinasi $\mathrm{kd} x_{2} \mathrm{y}=$ sebesar $63 \%$ Sedangkan sisanya 37 
Noerdjanah Rahayuningsih, Toandi

$\%$ dipengaruhi oleh faktor- faktor lainnya yang tidak diteliti.

6. Hubungan harga dan gaya hidup terhadap keputusan pembelian masuk dalam kategori sedang, dilihat dari hasil analisis korelasi yaitu: $r_{x 1 \times 2 y}=0,581$ dan adanya pengaruh harga dan gaya hidup terhadap keputusan pembelian dari hasil koefisien determinasi $\mathrm{kd}$ $x_{1} x_{2} y=$ sebesar $33,7 \%$ Sedangkan sisanya $66,3 \%$ dipengaruhi oleh faktor-faktor lainnya yang tidak diteliti.

Saran

Berdasarkan hasil penelitian yang dilakukan oleh peneliti di PT. Putra Mulya Citra Mobil Dealer Kawasaki Cirebon, peneliti mengungkapkan beberapa saran:

1. Harga motor di PT. Mulya Putra Citra Mobil Dealer Kawasaki Cirebon pada dasarnya sudah cukup baik akan tetapi harga harus lebih ditingkatkan lagi agar sesuai daya beli masyarakat cirebon.

2. Gaya Hidup konsuemen di PT. Mulya Putra Citra Mobil Dealer Kawasaki Cirebon pada dasarnya sudah cukup baik, yaitu sesuai dengan daya beli masyarakat Cirebon

3. Keputusan Pembelian di PT. Mulya Putra Citra Mobil Dealer Kawasaki Cirebon pada dasarnya sudah cukup baik, untuk mengoptimalkannya maka dibutuhkan jalinan hubungan baik kosumen dengan pihak PT. Mulya Putra Citra Mobil Dealer Kawasaki Cirebon

4. Harga merupakan satu diantara faktor-faktor yang mempengaruhi keputusan pembelian, oleh karena itu harga motor kawasaki alangkah baiknya jika dilakukan pemotongan harga agar konsumen melakukan pembelian ulang.

5. Gaya hidup merupakan satu diantara faktor-faktor yang mempengaruhi keputusan pembelian, oleh karena itu konsumen bisa melakukan pembelian motor kawasaki dengan mengikuti tren dan suka membelanjakan uangnya dalam membeli motor di PT. Putra Mulya Citra Mobil Cirebon.

6. Harga dan gaya hidup terhadap keputusan pembelian motor haruslah sesuai dengan kemampuan konsumen selera yang 
diinginkannya, maka PT. Mulya Putra Citra Mobil Dealer Kawasaki Cirebon harus memnyesuaikan harga motor dengan gaya hidup konsumen

\section{DAFTAR PUSTAKA}

Assauri Sofyan,2012. Manajemen Pemasaran, Erlangga.Jakarta

Ardiansyah.M, 2012. Manajemen Pemasaran Usaha, Pelita, Yogyakarta

Basu Swasta dan Irawan, 2010. Asasasas Marketing, Liberty, Yogyakarta

Fandy Tjiptono, 2015. Strategi Pemasaran Edisi 4, Andi. Yogyakarta.

Hsu dan Chang dalam setyaji,2008. Pemasaran Strategik, Liberty. Yogyakarta

Husein Umar, 2008. Metode Penelitian untuk Skripsi dan Tesis, Gramedia Pustaka Utama.Jakarta

Kottler dan Amstrong, 2009. Prinsipprinsip Pemasaran edisi kedelapan, Erlangga, Jakarta.

Kottler dan Kaller, 2009. Manajemen Pemasaran, edisi tigabelas, Erlangga, Jakarta
M.Iqbal Hasan, 2012.Pokok-pokok materi metodelogi penelitian dan aplikasinya, Ghalia,Bogor

Philip Kottler, 2010. Manajemen Pemasaran Edisi Millenium, Erlangga, Jakarta

Sangadji dan Sopiah, 2013. Perilaku Konsumen, Erlangga.Jakarta Sugiyono, 2013. Metode Penelitian Bisnis, Alfabeta,Bandung. http://eprints.undip.ac.id/28746///Jurnal .pdf 